Neurochemical Research, Vol. 7, No. 6, 1982

\title{
PROTEIN SYNTHESIS AND TRANSPORT IN THE REGENERATING GOLDFISH VISUAL SYSTEM
}

\author{
Anne M. Heacock and Bernard W. Agranoff \\ Neuroscience Laboratory Building \\ The University of Michigan \\ Ann Arbor, Michigan 48109
}

Accepted March 12, 1982

\begin{abstract}
The nature of the proteins synthesized in the goldfish retina and axonally transported to the tectum during optic nerve regeneration has been examined. Electrophoretic analysis of labeled soluble retinal proteins by fluorography verified our previous observation of a greatly enhanced synthesis of the microtubule subunits. In addition, labeling of a tubulin-like protein in the retinal particulate fraction was also increased during regeneration. Like soluble tubulin, the particulate material had an apparent MW of 53-55K and could be tyrosylated in the presence of cycloheximide and $\left[{ }^{3} \mathrm{H}\right]$ tyrosine. Comparison of post-crush and normal retinal proteins by two-dimensional gel electrophoresis also revealed a marked enhancement in the labeling of two acidic $68-70 \mathrm{~K}$ proteins. Analysis of proteins slowly transported to the optic tectum revealed changes following nerve crush similar to those observed in the retina, with enhanced labeling of both soluble and particulate tubulin and of $68-70 \mathrm{~K}$ polypeptides. The most striking change in the profile of rapidly transported protein was the appearance of a labeled $45 \mathrm{~K}$ protein which was barely detectable in control fish.
\end{abstract}

\section{INTRODUCTION}

Following optic nerve section, the retinal ganglion cells of the goldfish regenerate and reestablish appropriate connections in the optic tectum. Since this regenerative capacity is lacking in the central nervous systems of higher species, the goldfish visual system has been the subject of much electrophysiological and anatomical (1), and more recently, biochemical investigations. The latter studies have revealed alterations in nucleic acid (2-4) and protein metabolism (5-7). Both the level of protein synthesis 
in the retinal ganglion cell (5) and the amount of labeled axonally transported protein (8) have been reported to be elevated 3 to 5 -fold following optic nerve crush or tract section. While in a previous study of retinal protein synthesis (6) we observed only an increased labeling of tubulin following axotomy, it may be that alterations in minor proteins were masked by the contribution of the other retinal elements, since the ganglion cells represent only about $5 \%$ of the retinal cells. Analysis of the proteins which undergo axonal transport from the retina to the optic tectum offers a means to examine specifically those proteins synthesized by the retinal ganglion cell. Such an approach has recently proved useful in studies of regeneration in the toad (9) and rabbit (10), as well as in the goldfish (11). A parallel examination of retina labeling is also desirable in order to determine if an alteration in transport reflects altered retinal protein synthesis. In this report, we have used high resolution one- and two-dimensional slab gel electrophoresis coupled with fluorography to analyze both the proteins synthesized by the whole retina and those which are undergoing rapid and slow axonal transport to the optic tectum. Part of this work has been reported in preliminary from (12).

\section{EXPERIMENTAL PROCEDURE}

Optic Nerve Crush. Goldfish (Carassius auratus, Ozark Fisheries, Stoutland, Missouri), 6-7 cm in body length, were anesthetized with tricaine methane sulfonate (Finquel, Ayerst) prior to intraorbital crush of the right optic nerve. Fish were housed in aerated tanks at 21 $\pm 1^{\circ} \mathrm{C}$ and were fed daily.

Protein Labeling. Protein synthesis in post-crush and normal retinas was compared by incubating groups of 5 right and left retinas separately, in vitro, with $50 \mu \mathrm{Ci} / \mathrm{ml}$ of L-[4,5${ }^{3} \mathrm{H}$ ]leucine (60 Ci/mmol, New England Nuclear) in the medium of Dunlop et al. (13) for 1 $\mathrm{hr}$ at $25^{\circ} \mathrm{C}$. For examination of tyrosylation of tubulin, retinas were incubated with $60 \mu \mathrm{Ci} /$ $\mathrm{ml}$ of L-[ring-3,5- ${ }^{3} \mathrm{H}$ ]tyrosine $(53 \mathrm{Ci} / \mathrm{mmol}$, New England Nuclear) and $100 \mu \mathrm{g} / \mathrm{ml}$ of cycloheximide for 1 to $4 \mathrm{hrs}$. Retinas were then rinsed in ice cold saline and stored at $-20^{\circ} \mathrm{C}$. For labeling of axonally transported proteins, control or post-crush tısh (5-10 per group) were injected intraocularly (IO), in the right eye, with $10-50 \mu \mathrm{Ci}$ of $\mathrm{L}-\left[2,3-{ }^{3} \mathrm{H}\right]$ proline $(20-40$ $\mathrm{Ci} / \mathrm{mmol}$, New England Nuclear) in $5 \mu \mathrm{l}$. After $6 \mathrm{hr}$ to 30 day, optic tecta (and for some experiments, optic nerve and tract as well) were removed, frozen over dry ice and stored at $-20^{\circ} \mathrm{C}$.

Gel Electrophoresis. Tissue pooled from 5-10 fish was homogenized in 0.2-0.5 $\mathrm{ml}$ of 62.5 $\mathrm{mM}$ Tris- $\mathrm{HCl}$ (pH 6.8), $1 \mathrm{mM}$ EDTA, $1 \mathrm{mM}$ phenylmethylsulfonylfluoride, then centrifuged at $100,000 \mathrm{~g}$ for $1 \mathrm{hr}$ at $4^{\circ} \mathrm{C}$. The resulting supernatant was brought to a final concentration of $1-2 \%$ in SDS, $8 \mathrm{M}$ in urea and $5 \%$ in mercaptoethanol. The pellet was washed by resuspension in the homogenization medium followed by recentrifugation. The final pellet was solubilized in the SDS-urea buffer and centrifuged at $20^{\circ} \mathrm{C}$ for $2 \mathrm{hr}$ at $100,000 \mathrm{~g}$ to remove insoluble material (less than $10 \%$ of the total radioactivity). Samples were stored at $-70^{\circ} \mathrm{C}$ prior to one- or two-dimensional electrophoresis on $10 \%$ polyacrylamide slab gels (14). Gels were stained with Coomassie Blue and the radioactive proteins were detected by fluoro- 
graphy (15). For a given gel the same amount of radioactivity was applied to each lane so that the exposure times (30-90 days) would be comparable. Trichloroacetic acid precipitable radioactivity was determined by a filter paper method (16) and protein concentration was measured spectrophotometrically (17). For quantitation of radioactivity in the gels, $1 \mathrm{~mm}$ slices from stained gels were dissolved with hydrogen peroxide prior to scintillation counting. In some experiments, protein was extracted from gel slices by stirring the macerated gel in $2 \%$ SDS overnight, then filtering to remove the acrylamide. The protein solution was dialyzed against $0.1 \%$ SDS, concentrated by lyophilization, then rerun on two-dimensional gels. The approximate position of tubulin in unstained gels was detected by applying samples of dansylated bovine serum albumin $(68 \mathrm{~K})$ and ovalbumin $(45 \mathrm{~K})$ to adjacent lanes.

\section{RESULTS}

Retina Labeling. The soluble and particulate fractions from 15 day postcrush (PC) and normal $(\mathrm{N})$ retinas labeled in vitro with $\left[{ }^{3} \mathrm{H}\right]$ leucine were analyzed by SDS-slab gel electrophoresis (Figure 1). In the soluble fraction, the expected enhanced labeling in the tubulin region $(55 \mathrm{~K})$ was observed. In addition, labeling of bands at approximately 75,68 , and $23 \mathrm{~K}$ appeared to be elevated, as well as a $45 \mathrm{~K}$ band which may correspond to actin (7). Similar results were obtained from 11 and 18 day PC retinas. The particulate fraction also contained proteins, in the molecular weight range of the tubulin subunits, whose labeling was increased in the postcrush retina.

Two-dimensional gel electrophoresis of the retina-soluble fraction (Figure 2) revealed an even more striking increase in the labeling of the tubulin subunits in the $\mathrm{PC}$ retina than was seen in one-dimensional gels. Of several other apparent differences, the most obvious was the presence in the PCsoluble fraction of proteins of $68-70 \mathrm{~K}(\mathrm{pI}=4.8-4.9)$ which were nearly undetectable in the fluorography of the $\mathrm{N}$ retina or by Coomassie Blue staining. The size and isoelectric point of this cluster of proteins corresponded to that described for one of the subunits of mammalian neurofilaments (18). While two-dimensional gel electrophoresis of the particulate fraction did reveal labeling of tubulin (see below, Figure 7), this fraction was not further analyzed because excessive streaking in the isoelectric focusing gel caused migration artifacts and limited the resolution.

Time Course of Nerve Regrowth into Tectum and Rapid Axonal Transport. Regrowth of regenerating optic nerve fibers was assessed by measurement of the appearance of rapidly transported protein in the contralateral optic tectum. Normal and post-crush fish were iniected intraocularly with $\left[{ }^{3} \mathrm{H}\right]$ proline in the right eye and protein-bound radioactivity in the contralateral and ipsilateral tecta was determined at $24 \mathrm{hr}$ (Figure 3A). Since the optic nerves in the goldfish are virtually completely crossed, the 


\section{SOLUBLE PARTICULATE}

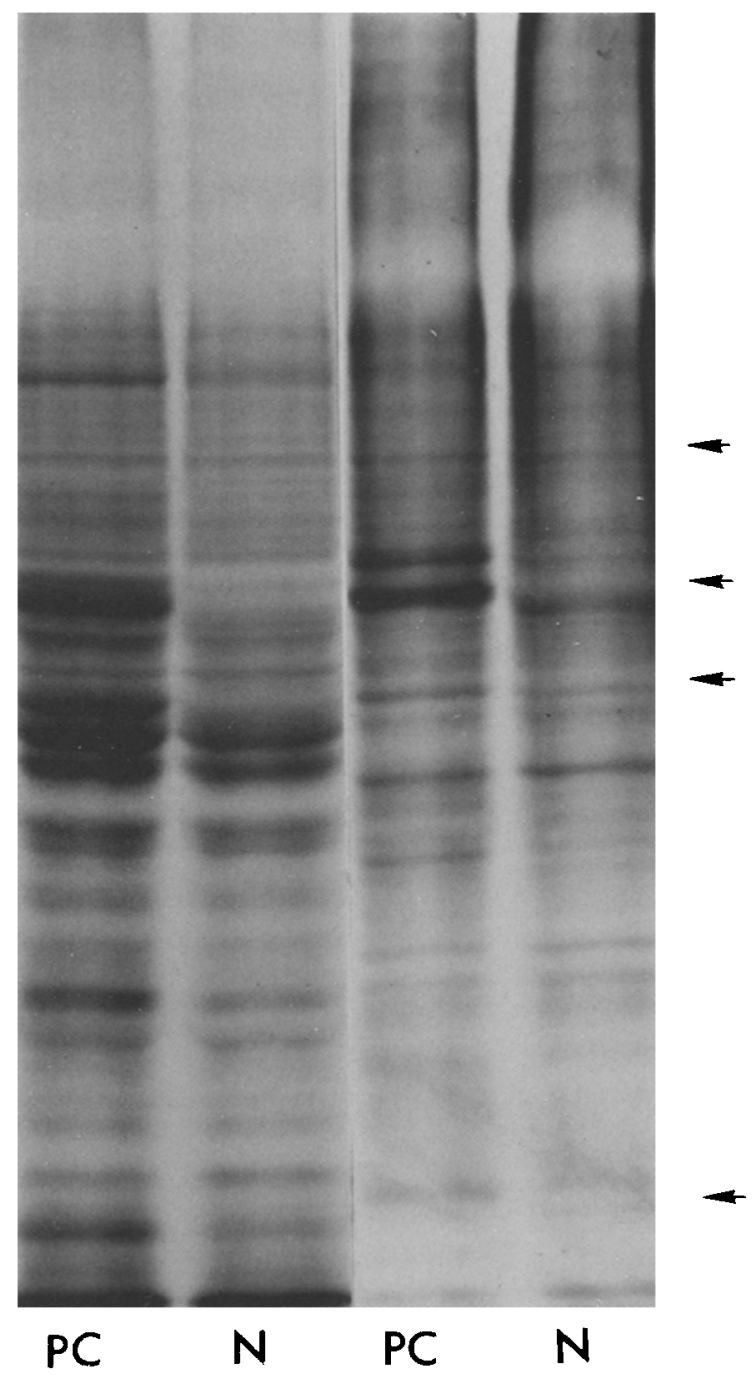

FIG. 1. Fluorography of SDS gel of $\left[{ }^{3} \mathrm{H}\right]$ leucine-labeled soluble and particulate proteins from 15 day $\mathrm{PC}$ or $\mathrm{N}$ retinas. Arrows indicate the positions of $68,55,45$ and $14 \mathrm{~K}$ molecular weight standards. 

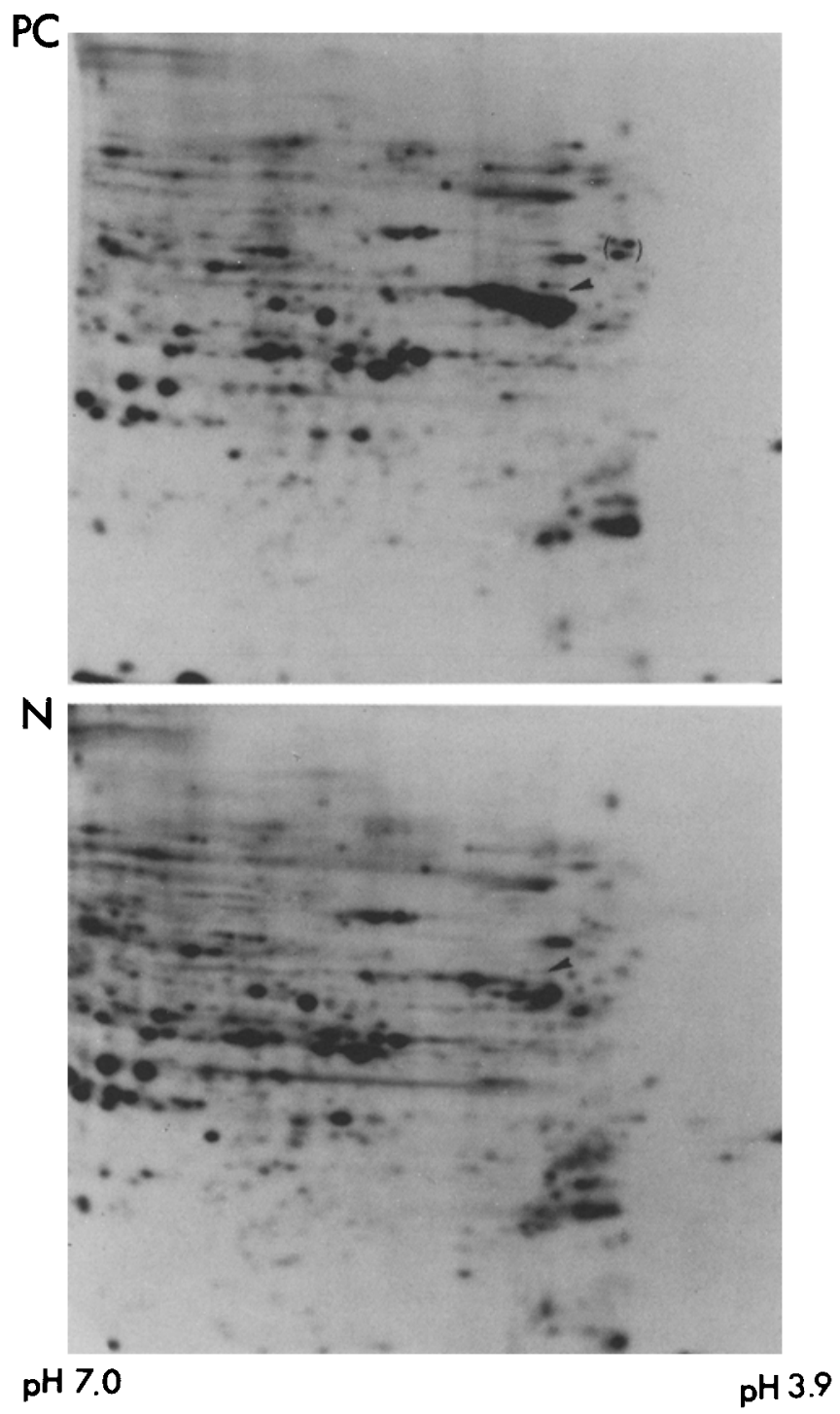

FIG. 2. Fluorography of two-dimensional gel of $\left[{ }^{3} \mathrm{H}\right]$ leucine-labeled soluble fractions from 15 day PC or $\mathrm{N}$ retinas. Arrow marks the position of the tubulin subunits; ( ) indicates the 68-70K proteins. The same total amount of radioactivity was applied to each gel. 
A

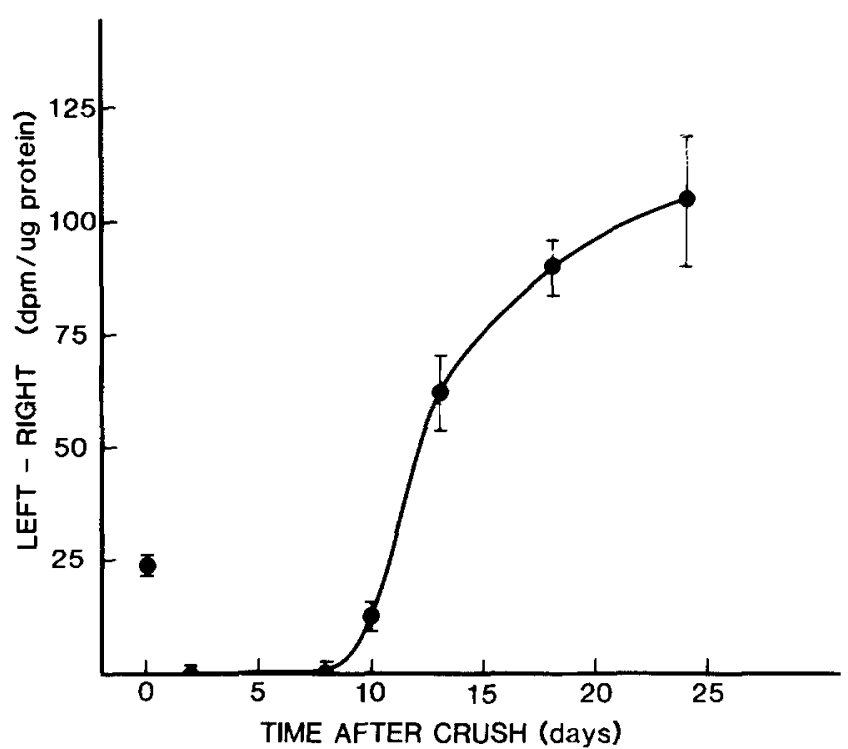

B

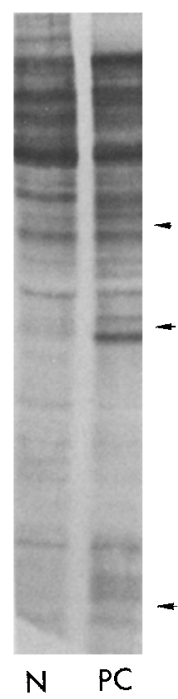

FIG. 3. A. Time course of regrowth of regenerating optic nerve measured by rapid axonal transport of labeled protein. Radioactivity in both optic tecta was determined at $24 \mathrm{hrs}$ following intraocular injection (right eye) of $\left[{ }^{3} \mathrm{H}\right]$ proline. Values are mean $\pm \operatorname{SEM}(n=3$ groups of five fish). B. Fluorography of rapidly transported protein in $\mathrm{N}$ or 2.5 day PC fish. Left tecta were prepared for electrophoresis 6 hrs follo right eye. Arrows indicate the positions of 68,45 and $14 \mathrm{~K}$ molecular weight standards.

right or ipsilateral tectum serves as a control for systemic labeling. The latter is negligible with $\left[{ }^{3} \mathrm{H}\right]$ proline as precursor (19). The arrival of transported protein, indicating that the regenerating nerve had reached the contralateral tectum, was first detectable at 10 days post-crush, with a steep increase up to 18 days and some leveling off by 24 days. At the later time, the amount of radioactivity transported to the tectum was 4fold higher than in normal fish. In other individual experiments in which paired groups of fish were analyzed, the post-crush/normal ratio of labeled rapidly transported protein was found to be as much as 10:1.

With this information on the time course of axon regrowth, rapidly transported protein arriving in the optic tectum was examined by gel electrophoresis at 25-26 days post-crush, when the majority of the fibers had reached the tectum, but before visual function had been restored (20). Since greater than $95 \%$ of the protein carried by fast axonal transport was particulate, the whole homogenate of these samples was applied to the gels (Figure 3B). Despite the greatly increased amount of radioactivity 
incorporated, rapidly transported protein from the PC visual system showed a labeling pattern quite similar to that of normal fish except for bands of $43-45 \mathrm{~K}$ and of higher molecular weight, which were enhanced during regeneration.

Slowly Transported Proteins. Previous studies of axonal transport in the intact goldfish visual system (21) have shown that slowly transported proteins are detectable in the optic tectum as early as 8 days following intraocular injection of labeled precursor. Radioactivity in the tectum continues to increase for the next 15 days after which there is a leveling off, followed by a gradual decline (21). Slowly transported protein arriving in the tectum was therefore examined electrophoretically at 10 or 30 days following intraocular injection of $\left[{ }^{3} \mathrm{H}\right]$ proline. At both times and in postcrush or normal fish, approximately one-third of the labeled transported protein was in the $100,000 \mathrm{~g}$ soluble fraction. The specific radioactivity of the 14 day PC samples was approximately 10-fold higher than that of the $\mathrm{N}$ samples. The labeling pattern of the slowly transported soluble proteins did not change between the 10 day and 30 day postinjection interval (Figure 4A). Comparison of 14 day $\mathrm{PC}$ and $\mathrm{N}$ fish revealed a marked enhancement of labeling of the 53-55K region, suggesting an increased transport of tubulin in the regenerating optic nerve. Bands at $45 \mathrm{~K}$ and $68 \mathrm{~K}$ were also more highly labeled in the PC fish, while there was an apparent decline in labeling of some lower molecular weight bands. These differences persisted in fish injected with precursor at 25 days PC, but by 50 days PC the pattern had essentially returned to normal (Figure 4B). Quantitation of radioactivity revealed a 4 to 5 -fold increase in the relative amount of tubulin labeling in 14 day PC samples (Figure 4A) which, when corrected for the 10-fold higher specific activity of the PC tecta, indicates a 40 to 50 -fold increase.

In the particulate fraction, the most prominent alteration in the PC fish was also an enhanced labeling of a band co-migrating with tubulin. The possibility that soluble tubulin might have been trapped in the pellet, even after extensive washing, was examined by a mixing experiment in which labeled soluble protein from PC fish was mixed with an unlabeled pellet fraction, rehomogenized and re-centrifuged. The resulting washed pellet retained less than $6 \%$ of the soluble radioactivity, indicating that there was little contamination of the particulate fraction with soluble tubulin.

In order to examine the possibility that local synthesis in the tectum due to reutilization of precursor (22) might contribute to the observed labeling pattern, tectal proteins labeled following intracranial injection of $\left[{ }^{3} \mathrm{H}\right]$ proline were analyzed by electrophoresis (Figure 4A; lanes 1,10 ). Locally synthesized proteins were found to differ considerably from those labeled following intraocular injection. In addition, no differences be- 


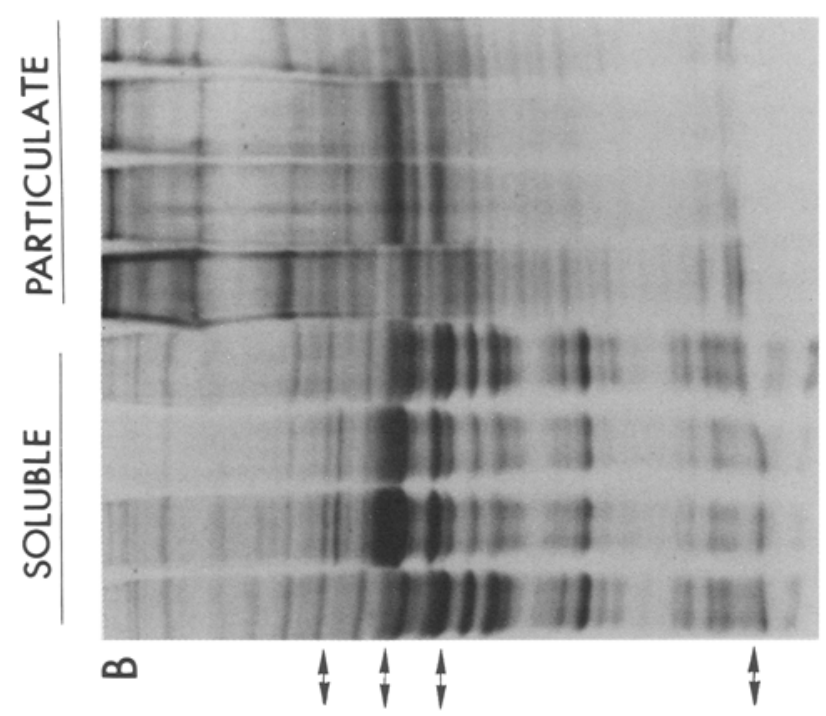

은

议记

$\sim$ 乎

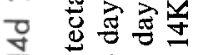

- \pm 음

Z 焉焉范 宁守

- 范. 的

을.

으유.

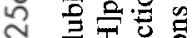

긍 可

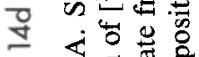
$<$ 焉

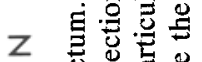

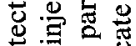

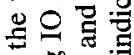

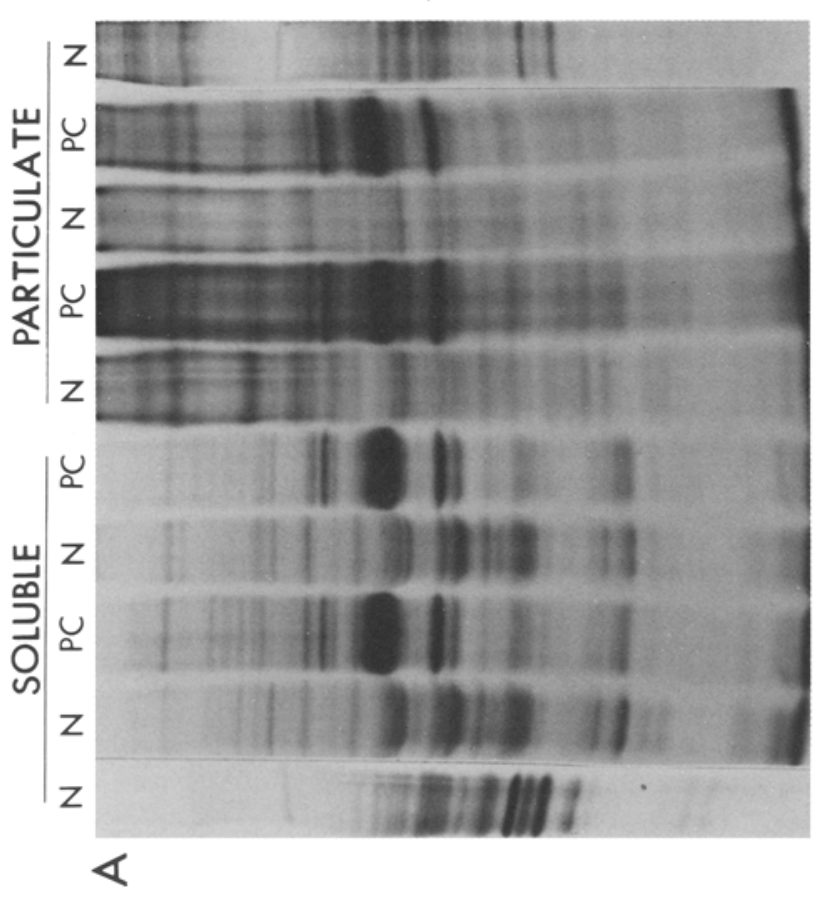

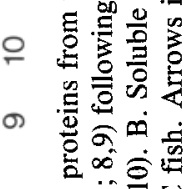

$\infty \quad \vec{d} \ddot{q}=$

范公

- 总焉焉导

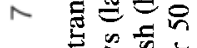
包递

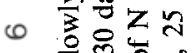
के 岁壱 5

ம

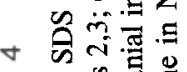

पै 苛

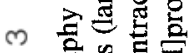

象竞

항 要

N

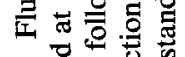

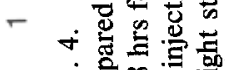

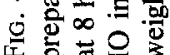


tween $\mathrm{PC}$ and $\mathrm{N}$ tecta protein labeling patterns were observed following intracranial injection.

Since very little transported tubulin (and no detectable $68-70 \mathrm{~K}$ protein) had arrived in the normal tectum even by the 30 day interval, optic nerve and tract were also examined to determine if slow transport in the normal nerve was delayed relative to that in the regenerating nerve (Figure 5). Labeling of soluble tubulin in the PC tract was found to be enhanced compared to the normal tract, while in the nerve the reverse seemed to be true, a result compatible with an enhanced rate of transport of tubulin in the regenerating nerve. Nevertheless, the total amount of labeled tubulin in the nerve, tract and tectum (Figures 4, 5) of PC fish remained greatly elevated over that in normal fish. The $68-70 \mathrm{~K}$ protein was faintly labeled in the normal nerve and tract, while the PC samples showed heavy labeling in this region of the gel, with some dissociation between the transport of this protein and the microtubule subunits apparent. These results suggest that at least some of the $68-70 \mathrm{~K}$ protein is transported more rapidly during regeneration. Both the $\mathrm{N}$ and $\mathrm{PC}$ particulate fractions show labeled bands comigrating with tubulin, although the relative amounts of soluble and particulate $53-55 \mathrm{~K}$ proteins vary considerably among nerve, tract and tectal samples.

Two-Dimensional Gel Electrophoresis of Transported Proteins. Slowly transported soluble proteins were then analyzed by two-dimensional gel electrophoresis to further characterize the presumptive tubulin and other proteins whose labeling is altered in PC fish. The labeling patterns from tectal samples obtained 30 days after injection of precursor in 14 day PC or $\mathrm{N}$ fish (Figure 6) were much simpler than those from the retina but reveal similar differences between the $\mathrm{PC}$ and $\mathrm{N}$ samples, i.e., a markedly enhanced labeling of the $\alpha$ - and $\beta$-subunits of tubulin, increased prominence of a $45 \mathrm{~K}$ protein and the appearance of labeled spots at $68-70 \mathrm{~K}$. While some labeled proteins were reduced or absent in the PC gel when compared to the $\mathrm{N}$ sample, this may be more apparent than real since each gel was exposed to X-ray film for a time proportional to the total amount of radioactivity applied. Thus, the high labeling of the tubulin subunits in the PC samples would tend to make other proteins appear relatively less labeled. Only transported tectal proteins were analyzed by two-dimensional gel electrophoresis, so that the identity of the $53-55 \mathrm{~K}$ and $68-70 \mathrm{~K}$ proteins with those labeled in the nerve and tract (Figure 5) remains to be established.

Characterization of Particulate Tubulin-Like Protein. The labeled particulate proteins comigrating with tubulin in the PC retina and in the slowly transported PC samples were not solubilized following homogenization in EGTA $(1 \mathrm{mM})$ or high salt $(1 \mathrm{M} \mathrm{NaCl})$ and were resistant to 


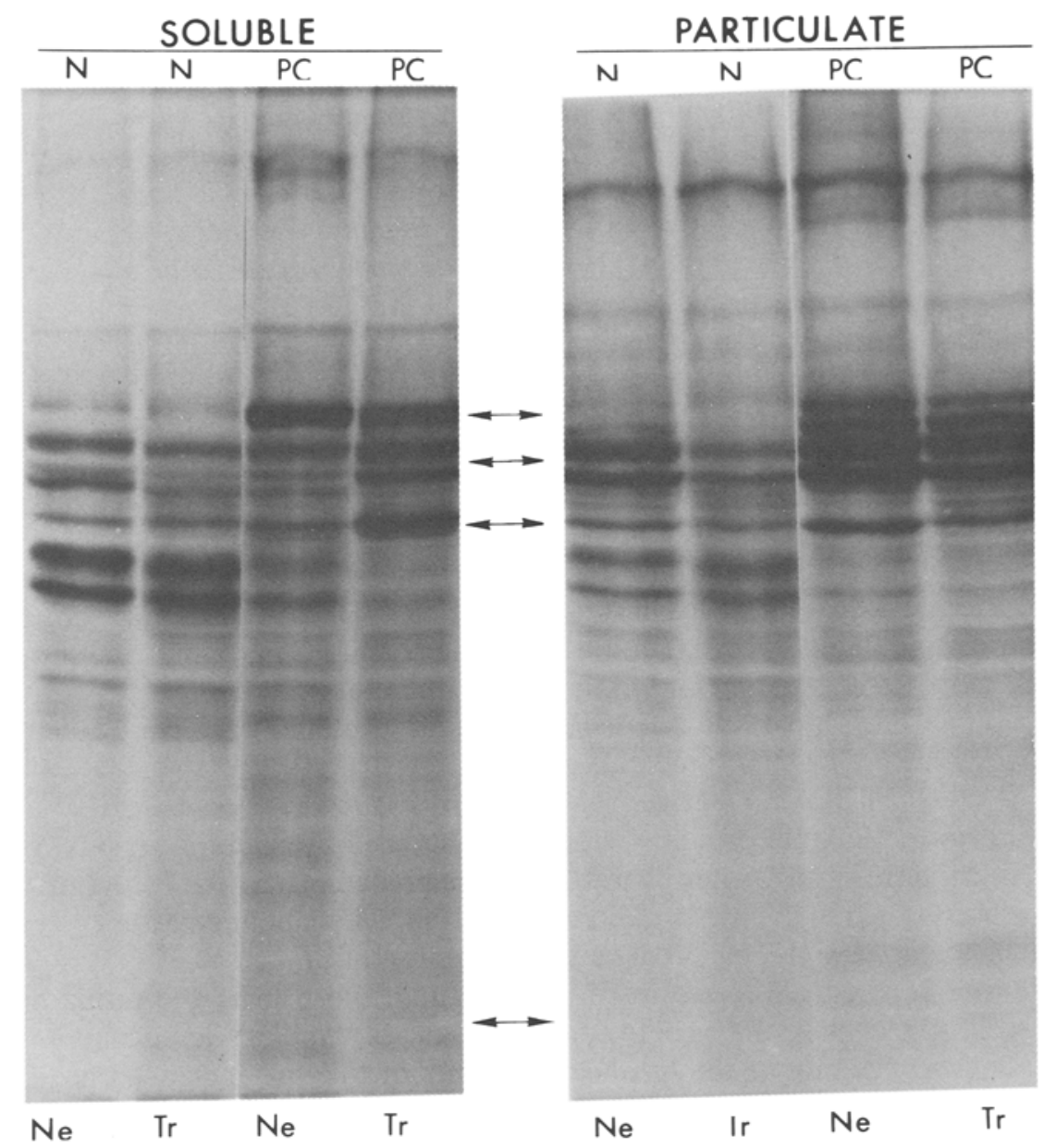

FIG, 5. Fluorography of SDS gels of slowly transported proteins from the optic nerve (Ne) and tract (Tr). At 30 days following IO injection with $\left[{ }^{3} \mathrm{H}\right]$ proline of 8 normal or 14 day PC fish, optic nerves (from the back of the eye to the chiasm) and optic tracts (form the chiasm to the tectum) were removed and soluble and particulate fractions were prepared. Arrows indicate the positions of $68,55,45$ and $14 \mathrm{~K}$ molecular weight standards.

extraction by detergents $\left(0.1-1 \%\right.$ Triton $\mathrm{X}-100$ or Nonidet $\mathrm{P}-40 ; 0^{\circ} \mathrm{C}$ for $30 \mathrm{~min}$ ) and to depolymerization by $10^{-4} \mathrm{M}$ colchicine (23). These observations suggest that the particulate tubulin-like protein is a membrane constituent and is not due to contamination from the soluble component or to undissociated microtubules. 

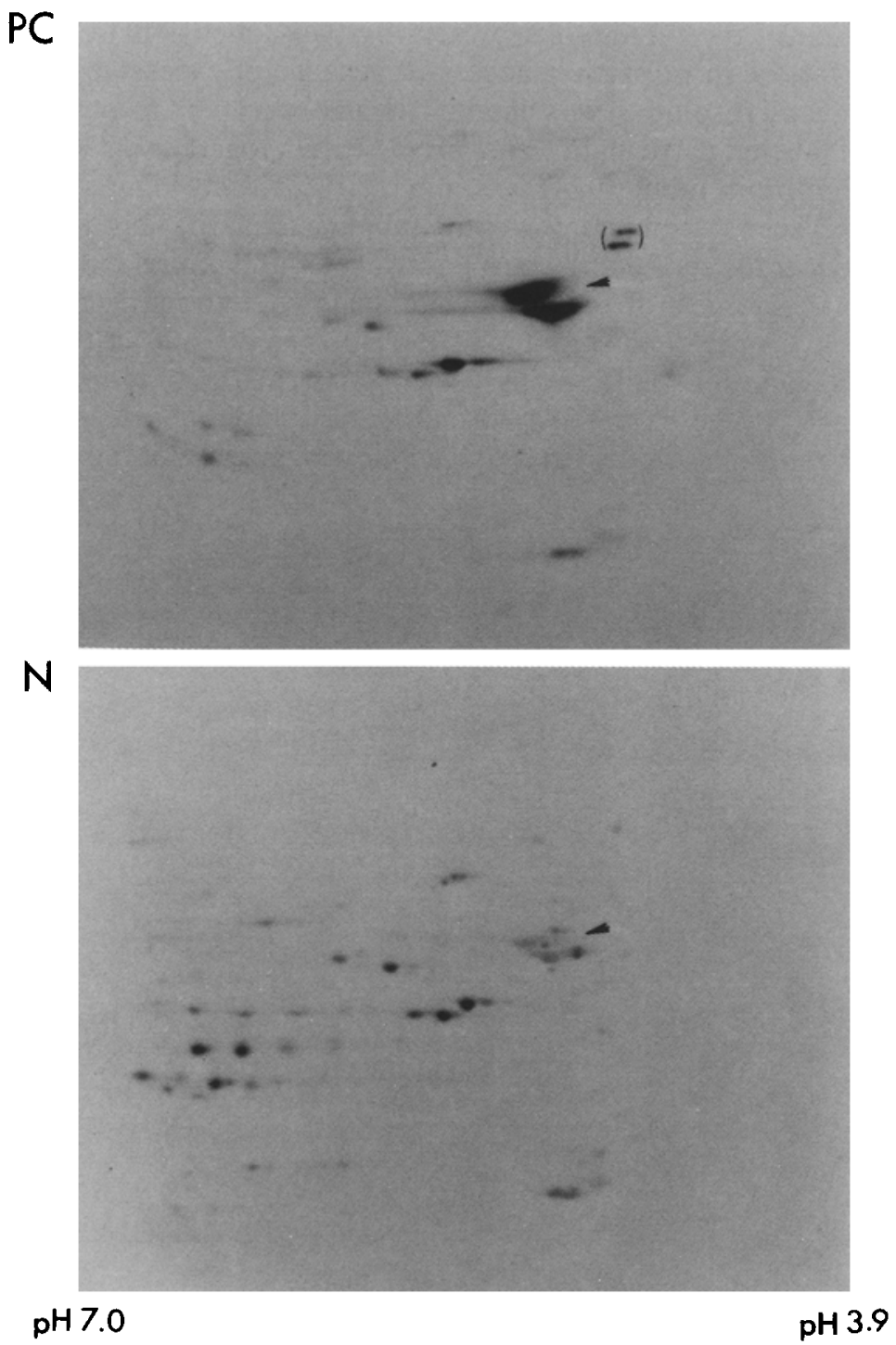

FIG. 6. Fluorography of two-dimensional gel of slowly transported soluble protein prepared at 30 days following IO injection of $\left[{ }^{3} \mathrm{H}\right]$ proline in $\mathrm{N}$ and 14 day PC fish. Arrow marks the position of the tubulin subunits; ( ) indicates the $68-70 \mathrm{~K}$ proteins. The same total amount of radioactivity was applied to each gel. 
Resolution of the tubulin-like protein by two-dimensional electrophoresis was for the most part unsuccessful because of excessive streaking. However, good resolution was obtained in an experiment in which a small amount of labeled particulate transported protein together with unlabeled purified fish brain tubulin (24) was applied to the gel (Figure 7). Radioactivity was seen to comigrate with the tubulin standard. This observation was subsequently verified by cutting the labeled tubulin region from onedimensional slab gels of the particulate samples, extracting the protein from the acrylamide and rerunning the extracted protein on two-dimensional gels. Scintillation counting of gel slices showed that over $80 \%$ of the radioactivity co-migrated with authentic tubulin. Since only tectal samples from 14 day PC fish at 30 days following precursor injection were

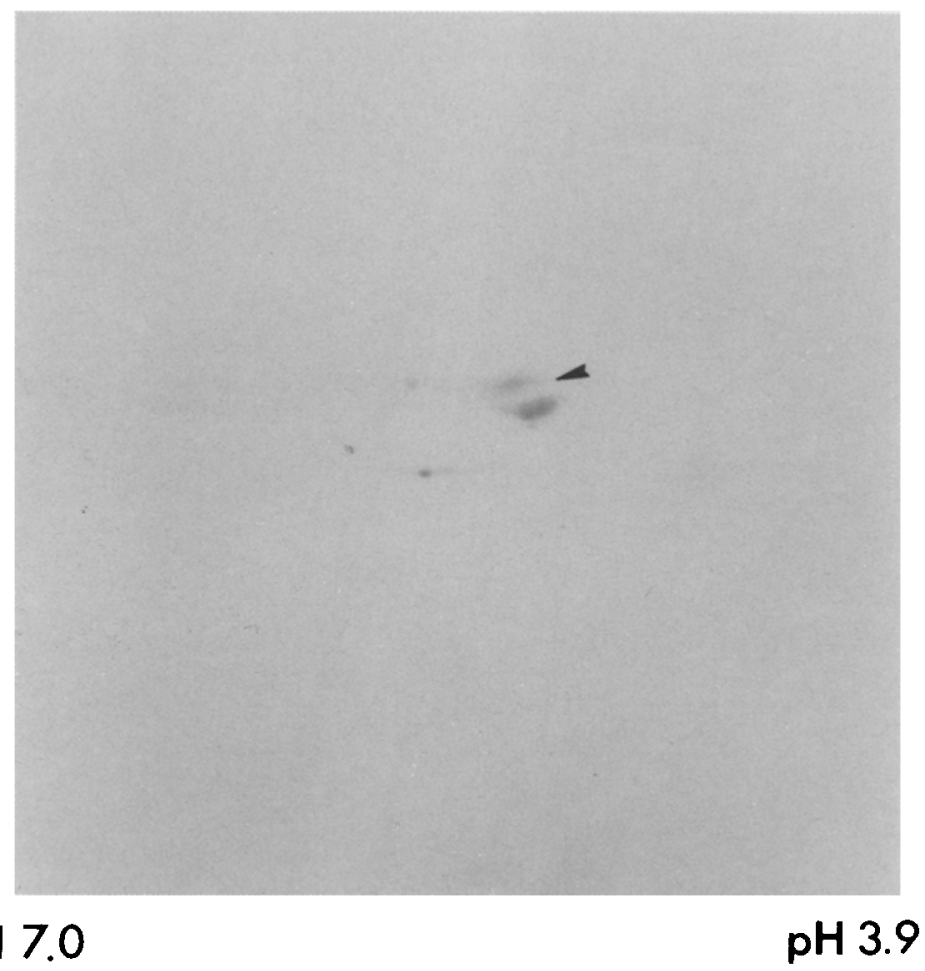

FIG. 7. Fluorography of two-dimensional gel of slowly transported particulate protein prepared at 30 days following IO injection of $\left[{ }^{3} \mathrm{H}\right]$ proline in 14 day PC fish. Ten $\mu \mathrm{g}$ unlabeled tubulin was added to the sample prior to electrophoresis. Arrow marks the position of the tubulin subunits. 


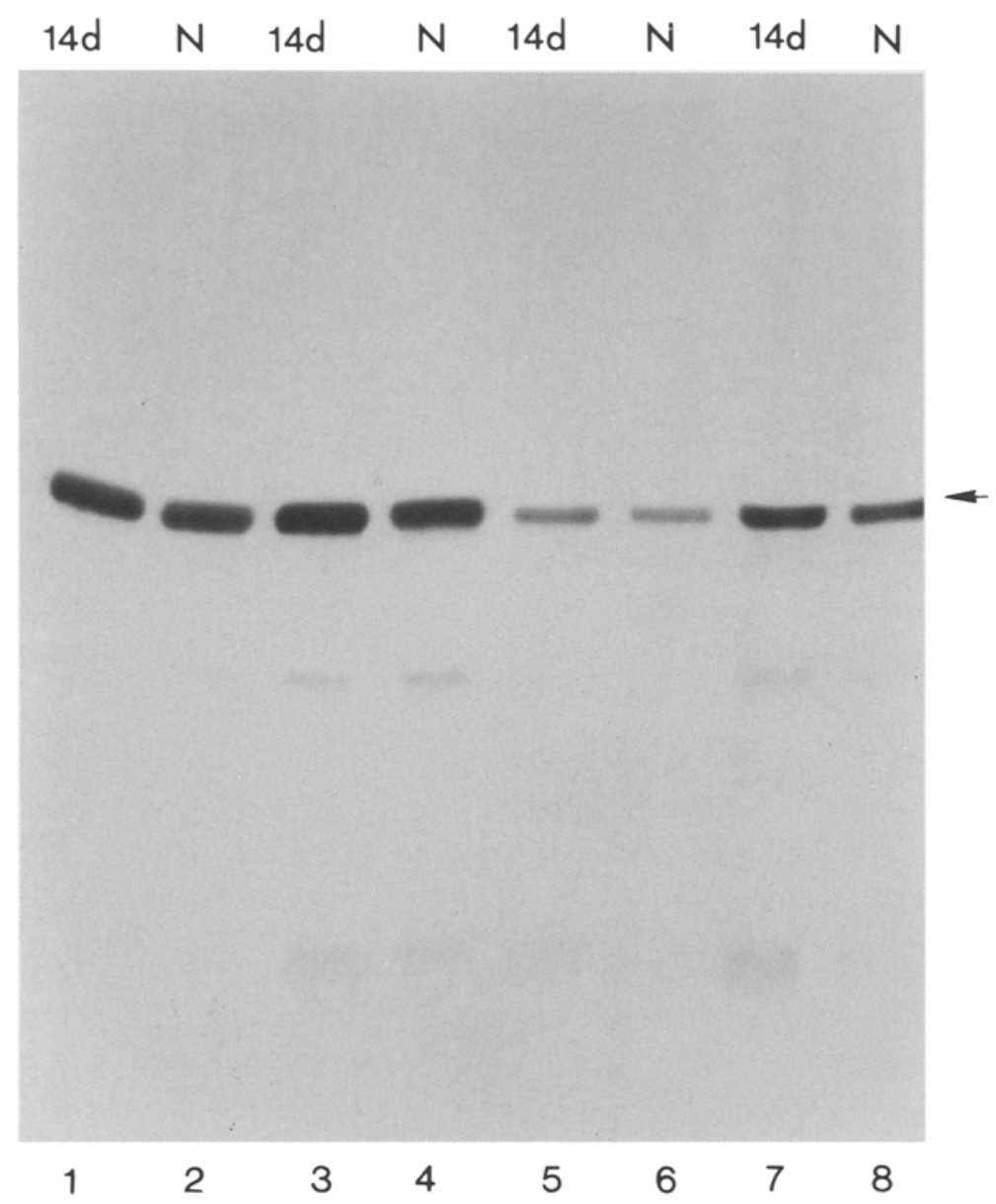

Fig. 8. Tyrosylation of soluble (lanes 1-4) and particulate (lanes 5-8) retina tubulin. Fluorography of SDS gel of soluble and particulate fractions from 14 day PC or $\mathrm{N}$ retinas, labeled for 1 (lanes 1,$2 ; 5,6$ ) or 4 hrs (lanes 3,$4 ; 7,8$ ) with $\left[{ }^{3} \mathrm{H}\right]$ tyrosine in the presence of cycloheximide. Arrow indicates position of tubulin standard.

analyzed in this way, it is not clear if the same would hold true for other post-injection intervals or for the optic nerve and tract (Figure 5).

Further support for the existence of membrane tubulin in the retina was obtained indirectly by examination of retinal proteins labeled in vitro with $\left[{ }^{3} \mathrm{H}\right]$ tyrosine in the presence of cycloheximide (Figure 8 ). Both sol- 
uble and washed particulate fractions exhibited a single labeled band comigrating with tubulin. Since the post-translational tyrosylation reaction appears to be restricted to tubulin $(25,26)$, the labeling of the particulate fraction is consistent with the existence of retinal membrane tubulin. PC and $\mathrm{N}$ retinas were equally labeled following incubation with $\left[{ }^{3} \mathrm{H}\right]$ tyrosine in the presence of cycloheximide.

\section{DISCUSSION}

In the process of regenerating its optic nerve, the goldfish retinal ganglion cell must synthesize and transport to the growing nerve macromolecular components necessary for the rebuilding of the axon and its eventual reconnection with the appropriate tectal target. Protein synthesis in general (5), and specifically that of tubulin (6) in the retina have previously been found to be increased during regeneration, as is the amount of labeled axonally transported protein (8). In the present study we have sought to further characterize the proteins synthesized and axonally transported by the retinal ganglion cell in response to axotomy. One- and twodimensional gel electrophoresis of labeled retina proteins confirmed the previous observation of enhanced labeling of the microtubule subunits and revealed a marked increase in the labeling of acidic proteins of $68-70 \mathrm{~K}$. The latter has a molecular weight and isoelectric point similar to that reported for one of the subunits of mammalian neurofilaments (18). The 68-70K labeled proteins and the tubulin subunits also constituted the major difference between $\mathrm{PC}$ and $\mathrm{N}$ slowly transported proteins. This observation is consistent with the assignment of the $68-70 \mathrm{~K}$ proteins as neurofilament subunits, since the latter are co-transported with tubulin in other species (27). However, Autilio-Gambetti et al. recently reported that the $68 \mathrm{~K}$ subunit was not detected in a goldfish brain neurofilament preparation (28). Additional possible candidates of approximately the same molecular weight are serum albumin or the microtubule associated "tau" proteins, but these proteins (29) and fish serum albumin (unpublished observation) have much more basic isoelectric points than does the $68-70 \mathrm{~K}$ protein described here.

The observed increase in the labeling of transported tubulin is in agreement with the recent findings of Skene and Willard in the regenerating toad visual system (9) and of Guilian et al. in the goldfish (7), and is similar in some respects to the results of Hoffman and Lasek (30) who described an increase in the rate of tubulin transport in the rat sciatic nerve 20 days post-lesion. The 40 to 50 -fold increase in the labeling of transported tubulin found in the present study does not seem to be ac- 
counted for by the 3-fold difference between PC and N retina tubulin labeling (6). While it might be argued that the increase in retinal ganglion cells could be much larger than that seen in the whole retina, analysis of a dissected ganglion cell preparation, following intraocular injection of precursor, revealed only a 4.5 -fold enhancement in tubulin labeling following axotomy (7). There appears then to be, in addition to the stimulation of retinal tubulin synthesis, an increase in both the amount of tubulin transported (Figures 4,5) and possibly in the rate of its transport (Figure 5). Another factor which could contribute to the enhanced tubulin labeling observed here is a decreased rate of degradation of cytoskeletal proteins in growing nerves, as outlined in the hypothesis of Lasek and Black (31).

The gel electrophoretic pattern of labeled rapidly transported protein was also found to be altered during optic nerve regeneration. The labeling of a protein of approximately $45 \mathrm{~K}$ was markedly increased at 25 days PC. This protein may correspond to the GAP-43 described by Skene and Willard (9) in the toad visual system and the rapidly transported $44 \mathrm{~K}$ protein found by Benowitz et al. (11), by a double label approach, to be increased during optic nerve regeneration in the goldfish.

We report here the presence of a tubulin-like protein in the particulate fraction of both the retina and the tectum, whose labeling and transport, along with that of soluble tubulin, is increased during regeneration. It has the same mobility as tubulin on two-dimensional gels and is also able to undergo post-translational tyrosylation, a reaction which appears to be restricted to tubulin. The material, tentatively identified as particulate tubulin, seems to be an intrinsic membrane protein, since it was not removed by several washing procedures, including detergent extraction. Several reports have described the existence of membrane-bound tubulin in various tissues, including brain $(32,33)$. Tubulin has been reported to be a component of synaptosomal plasma membranes (34), synaptic vesicle membranes (35) and of the axolemma of cultured superior cervical ganglion neurites (36). It is not clear from the present study whether tubulin is actually transported in a particulate or a soluble form prior to insertion into the appropriate membrane, although particulate tubulin appears to be present in both optic nerve and tract. In the tectum of 14 day PC fish, at 30 days following injection of precursor, labeled tubulin was approximately equally distributed between the soluble and particulate fractions. Transported tubulin in normal fish tectum was only faintly labeled, so that it was not possible to determine if the labeling ratio between soluble and particulate tubulin in the tectum was altered during regeneration.

The findings reported here, taken together with those from previous studies $(6,37)$, indicate that axotomy elicits an increase in the level of 
tubulin mRNA in the retina and a concomitant increase in tubulin synthesis and in the labeling of $68-70 \mathrm{~K}$ protein. There is also an enhanced axonal transport of these same proteins, which is not accounted for by their increased synthesis in the retina, suggesting that the normal level of transport of cytoskeletal components is not sufficient to support the elongation and/or restoration of axon caliber of the optic nerve. In addition, the labeling and transport of tubulin destined for insertion into membranes is also enhanced during regeneration. Although the function of membrane tubulin is not known, speculation has included a controlling effect on the motility of membrane proteins (38). It remains possible that membrane tubulin may play a critical role in the process of nerve growth and regeneration.

\section{ACKNOWLEDGMENTS}

This work was supported by NIMH grants NS 13743 and 12506. The authors thank Ms. Marianne Lewis for technical assistance.

\section{REFERENCES}

1. Jacobson, M. 1978. Developmental Neurobiology, Plenum Press, New York.

2. Murray, M. 1973. $\left[{ }^{3} \mathrm{H}\right]$ Uridine incorporation by regenerating retinal ganglion cells of goldfish. Exp. Neurol. 39:489-497.

3. Burrell, H. R., Dokas, L. A., and Agranoff, B. W. 1978. RNA metabolism in the goldfish retina during optic nerve regeneration. J. Neurochem. 31:289-298.

4. Dokas, L. A., Kohsaka, S., Burrell, H. R., and Agranoff, B. W. 1981. Uridine metabolism in the goldfish retina during optic nerve regeneration: Whole retina studies. J. Neurochem. 36:1160-1165.

5. Murray, M., and Grafstein, B. 1969. Changes in the morphology and amino acid incorporation of regenerating goldfish optic neurons. Exp. Neurol. 23:544-560.

6. Heacock, A. M., and AGRANOFF, B. W. 1976. Enhanced labeling of retinal protein during regeneration of optic nerve in goldfish. Proc. Natl. Acad. Sci. U.S.A. 73:828-832.

7. Giulian, D., DesRuisseaux, H., and Cowburn, D. 1980. Biosynthesis and intra-axonal transport of proteins during neuronal regeneration. J. Biol. Chem. 255:6494-6501.

8. Grafstein, B., and Murray, M. 1969. Transport of protein in goldfish optic nerve during regeneration. Exp. Neurol. 25:494-508.

9. Skene, J. H. P., and Willakd, M. 1981. Changes in axonally transported proteins during regeneration in toad retinal ganglion cells. J. Cell Biol. 89:86-95.

10. Skene, J, H. P., and Willard, M. 1981. Axonally transported proteins associated with growth in rabbit central and peripheral nervous system. J. Cell Biol. 89:96-103.

11. Benowitz, L. I., Shashoua, V. E., and Yoon, M. G. 1981. Specific changes in rapidly transported proteins during regeneration of the goldfish optic nerve. J. Neuroscience $1: 300-307$.

12. Heacock, A. M., Burrell, H. R., and Agranoff, B. W. 1978. Further studies of the biochemical consequences of optic nerve crush in the goldfish. Neurosci. Abstr. 4:1706.

13. Dunlop, D. S., VAN Elden, W., and LAJTHA, A. 1974. Measurement of rates of protein synthesis in rat brain slices. J. Neurochem. 22:821-830. 
14. O'Farrell, P. H. 1975. High resolution two-dimensional electrophoresis of proteins. J. Biol. Chem. 250:4007-4021.

15. Bonner, W. M., and Laskey, R. A. 1974. A film detection method for tritium-labeled proteins and nucleic acids in polyacrylamide gels. Eur. J. Biochem. 46:83-88.

16. Mans, P. J., and Novelli, G. D. 1961. Measurement of the incorporation of radioactive amino acids into protein by a filter paper method. Arch. Biochem. 94:48-53.

17. Lowry, O. H., Rosebrough, N. J., Farr, A. L., and Randall, R. J. 1951. Protein measurement with the Folin phenol reagent. J. Biol. Chem. 193:265-275.

18. Czosnek, H., SoIfer, D., and Wisniewski, H. M. 1980. Heterogeneity of intermediate filament proteins from rabbit spinal cord. Neurochem. Res. 5:777-793.

19. Elam, J. S., and Agranoff, B. W. 1971. Rapid transport of protein in the optic system of the goldfish. J. Neurochem. 18:375-387.

20. Springer, A. D. and Agranoff, B. W. 1977. Effects of temperature on rate of goldfish optic nerve regeneration: A radioautographic and behavioral study. Brain Res. 128:405-415.

21. Neale, J. H., El.am, J. S., Neale, E. A., and Agranoff, B. W. 1974. Axonal transport and turnover of proline- and leucine-labeled protein in the goldfish visual system. J. Neurochem. 23:1045-1055.

22. HeACOCK, A. M., and AgRanoff, B. W. 1977. Reutilization of precursor following axonal transport of $\left[{ }^{3} \mathrm{H}\right]$ proline-labeled protein. Brain Res. 122:243-254.

23. Feit, H., and Shay, J. W. 1980. The assembly of tubulin into membranes. Biochem. Biophys. Res. Commun. 94:324-331.

24. Shelanski, M. 1974. Methods for neurochemical study of microtubules. Pages 281-300, in MARK, N. and RoDnight, R. (eds.), Research Methods in Neurochemistry, 2, Plenum Press, New York.

25. Barra, H. S., Arce, C. A., Rodriguez, J. A., and Caputto, R. 1974. Some common properties of the protein that incorporates tyrosine as a single unit and the microtubule proteins. Biochem. Biophys. Res. Commun. 60:1384-1390.

26. Raybin, D., and Flavin, M. 1975. An enzyme tyrosylating $\alpha$-tubulin and its role in microtubule assembly. Biochem. Biophys. Res. Commun. 65:1088-1095.

27. Hoffman, P. N., and LASEK, R. J. 1975. The slow component of axonal transport. Identification of major structural polypeptides of the axon and their generality among mammalian neurons. J. Cell Biol. 66:351-366.

28. Autilio-Gambetti, L., Velasco, M. E., Sipple, J., and Gambetti, P. 1981. Immunochemical characterization of antisera to rat neurofilament subunits. J. Neurochem. 37:1260-1265.

29. Duerr, A., Pallas, D., and Solomon, F. 1981. Molecular analysis of cytoplasmic microtubules in situ: Identification of both widespread and specific proteins. Cell 24:203-211.

30. Hoffman, P. N., and Lasek, R. J. 1980. Axonal transport of the cytoskeleton in regenerating motor neurons: Constancy and change. Brain Res. 202:317-333.

31. LASEK, R. J., and BLACK, M. M, 1977. How do axons stop growing? Some clues from the metabolism of the proteins in the slow component of axonal transport. Pages 161-169, in Roberts, S., Lajtha, A., and Gispen, W. H., (eds.), Metabolism, Regulation and Special Functions of Protein Synthesis in the Brain, Elsevier/North-Holland Biomedical Press, Amsterdam.

32. Bhattacharyya, B., and WolfF, J. 1975. Membrane-bound tubulin in brain and thyroid tissue. J. Biol. Chem. 250:7639-7646.

33. Strocchi, P., Brown, B. A., Young, J. D., Bonventre, J. A., and Gllbert, J. M. 1981. The characterization of tubulin in CNS membrane fractions. J. Neurochem. 37:1295-1307.

34. Kelly, P. T., and Cotman, C. W. 1978. Synaptic proteins: Characterization of tubulin 
and actin and identification of a distinct postsynaptic density polypeptide. J. Cell Biol. 79:173-183.

35. ZisAPEL, N., Levi, M., and Gozes, I. 1980. Tubulin: An integral protein of mammalian synaptic vesicle membranes. J. Neurochem. 34:26-32.

36. Estridge, M. 1977. Polypeptides similiar to the $\alpha$ and $\beta$ subunits of tubulin are exposed on the neuronal surface. Nature 268:60-63.

37. Burrell, H. R., Heacock, A. M., Water, R. D., and Aranoff, B. W. 1979. Increased tubulin messenger RNA in the goldfish retina during optic nerve regeneration. Brain Res. 168:628-632.

38. Edelman, G. M. 1976. Surface modulation in cell recognition and cell growth. Science 192:218-226.

Note added in proof:

The possibility that the finding of membrane tubul in labeling might be an artifact of freezing (see Carlin et al., J. Neurochem. 38:94-99, 1982) was explored. No differences in labeled particulate tubulin were found between fresh and frozen tissue. 